\title{
Ortaokul Öğretim Programlarındaki Kazanımların Karakter Eğitimi Analizi*
}

\section{Character Education Analysis of Secondary School Curriculum Attainments**}

Özlem GÖKÇE TEKİN, Sorumlu Yazar, Doktora Öğrencisi. İnönü Üniversitesi, Eğitim Bilimleri Enstitüsü.

E-mail: ogokcetekin@gmail.com

ORCID: ORCID: 0000-0002-4436-3060

Gülay BEDIR, Doç. Dr.

Kahramanmaraş Sütçü İmam Üniversitesi. Eğitim Fakültesi.

E-mail: gulaybedir@hotmail.com

ORCID: 0000-0003-3488-6340

ISSN: 1303-880X

e-ISSN: 2667-7504

http://ded.dem.org.tr

Geliş/Received: 05.12.2018

Kabul/Accepted: 05.08.2019

Makale Yayın: 25.12.2019

Makale Türü/Article Type:

Araştırma/Research
Atıf/Citation: Gökçe Tekin, Ö. \& Bedir, G. (2019). Ortaokul öğretim programlarındaki kazanımların karakter eğitimi analizi. Değerler Eğitimi Dergisi,17 (38), 139-169. DOI: 10.34234/ded.492505

* Bu çalışma, "İlkokul ve Ortaokul Programlarının Karakter Eğitimi Açısından İncelenmesi” adlı yüksek lisans tezinden (Kahramanmaraş Sütçü İmam Üniversitesi Sosyal Bilimler Enstitüsü Eğitim Bilimleri Bölümü) üretilmiştir.

** This article is prepared from the master thesis titled "An Analysis of Character Education of Primary and Secondary Curriculum” (Kahramanmaraş Sütçü Imam University Institute of Social Sciences Department) 
Öz: Bu araştırmanın amacı ortaokul düzeyindeki bazı derslerin kazanımlar açısından karakter eğitimini ne ölçüde desteklediğini belirlemektir. Araştırmanın evrenini ortaokullara ait bütün derslerin öğretim programları oluşturmaktadır. Araştırmanın örneklemini ise ortaokul seviyesindeki zorunlu dersler oluşturmaktadır. Araştırma betimsel tarama modelindedir. Programların incelenmesi için dokümantasyon tekniği kullanılmıştır. Derslere ait öğretim programları, kazanımlar açısından karakter eğitiminin içerik ve kapsamına göre ele alınarak incelenmiştir. Ortaokul öğretim programlarının analizi için on dokuz karakter değerinden yararlanılmıştır. Verilerin analizi sonucunda ortaya çıkan sonuçlara göre derslerden hemen hepsinin karakter eğitimini belli ölçüde desteklediği belirlenmiştir. Karakter eğitimini en çok destekleyen ders ise Sosyal Bilgiler dersidir. Bu dersi Din Kültürü ve Ahlak Bilgisi, Beden Eğitimi ve Spor dersleri izlemektedir. Karakter eğitiminin içerik ve kapsamıla en az uyuşan dersin ise Türkçe dersi olduğu tespit edilmiştir. Araştırma sonunda ortaokul öğretim programlarının, karakter eğitiminin içerik ve kapsamına uygun olarak zenginleştirilip genişletilebileceği önerisi getirilmiştir. Karakter eğitimi ile ilgili kazanımların yetersiz olduğu Türkçe ve Fen Bilimleri gibi derslere ait kazanımların sayısı artırılabilir. İncelenen ortaokul öğretim programlarının kazanımlarında yer almayan alçakgönüllülük ve affetme değerlerine uygun kazanımlar oluşturulabilir. Sevgi, dürüstlük, iyimserlik, kibarlık/nezaket ve sportmenlik gibi karakter değerleri ile ilişkili kazanımların sayısı arttırılabilir.

Anahtar Kelimeler: Karakter, Karakter değeri, Karakter eğitimi, Öğretim program1.

$\&$

Abstract: This study aims to determine to what extent the attainments of some courses in secondary school programs support the character education. The sample of the research has been formed with compulsory courses (Turkish, Social Studies, Science, Religious Culture and Ethics, T.C. Revolution History and Kemalism, Guidance and Career Planning, Physical Education and Sports) at secondary school level in 2015-2016 academic year. Descriptive research model and documentation technique is used for the examination of the secondary school programs. The attainments in specified courses are discussed in terms of content and scope of character education as a whole. 19 character values are determined for the analysis of curriculum. In the programs, $19 \%$ of the attainments of secondary school curriculum are related to character education. Character education in secondary level is supported in almost all of the courses. The most supportive course is Social Studies. This course is followed by Reli- 
gious Culture and Ethics and Physical Education and Sports courses. It is found that lessons that are insufficient in terms of the attainments related to character education are Turkish and Science. It may be recommended that secondary school education programs can be enriched and expanded in terms of content and context of character education.

Key Words: Character, Character values, Character education, Curriculum.

\section{Giriş}

Son yıllarda şiddet, terör, dolandırıcılık gibi toplumsal düzeni bozan olaylar gerek ülkemizde gerekse yurt dışında artış göstermektedir. Bu olayların meydana gelmesinin temelinde ise kişilerin karakter özellikleri yer almaktadır. Olumsuz karakter özelliklerine sahip bireylerin kendisine olduğu kadar topluma da zarar vermesi kaçınılmazdır.

Karakter kavramının Osmanlıca karşıllı̆̆ "seciye", İngilizce karşıllı̆ı ise “character"dir. Karakter, Türk Dil Kurumu'nda en genel biçimde "Bir bireyin kendine özgü yapısı, onu başkalarından ayıran temel belirti ve bireyin davranış biçimlerini belirleyen, üstün ana özellik, öz yapı, ıra, seciye" olarak tanımlanmaktadır.

Ekşi ve Katılmış’ a (2015) göre karakter, insanın zihinsel, duygusal ve bedensel etkinliklerinin sonucunda ortaya çıkan davranışlarına çevrenin verdiği değerdir. Karakter, ruha yerleşen erdemlerden dişa vuran alametler ve alametlerin tamamı anlamında kullanılmaktadır. Yardımseverlik, dürüstlük, cesaret vb. bir karakter özelliği olarak kabul edilir. Bu özeliklerin bireyin ruhunda yer etmiş hali için karakter, bu özelliklere sahip kişi için de karakterli nitelemesi kullanılır (Meydan, 2012).

Karakter eğitimi ise, ahlaki değer anlayışına sahip ve doğruyu seçebilen bireylerin yetiştirilmesi amacıyla öğrencilerin çeşitli sosyal ortamlarda uygun bir şekilde nasıl davranacaklarına karar verme yeteneklerini geliştirmenin öğretilmesidir (Almerico, 2014). Bakioğlu ve Sılay (2014) karakter eğitimini öğrencilere, iyi ile kötüyü ayırt etmelerine ve iyi davranışlar sergilemelerine yardımcı olma rolü olarak tanımlanmıştır. Bu bağlamda karakter eğitiminin hedefinin iyi tercihler yapıp hayatımızı o yönde sürdürmek için pratik zekâ ve ahlak anlayışına sahip öğrenciler yetiştirmek olduğu söylenebilir.

Character Education Informational Handbook ve Guide (2001: 2) karakter eğitiminin özelliklerini şöyle sıralamıştır. 
Karakter eğitimi;

- Model alma, ortamın oluşturulması ve öğretim programı yoluyla öğretilebilir.

- Aile, toplum ve okulun katılımını gerektirir.

- Var olan eğitim materyallerini adapte ederek ve kullanarak anlamayı destekleyen ve öğrenme deneyiminin her evresinde tüm öğrencilere iyi bir karakter gelişiminin özendirilmesi için aktif bir yoldur.

- Nasıl doğru kararlar alınacağını ve iyi seçimler yapmayı öğrenmektir.

- Olumlu ilişkiler ve bu olumlu ilişkilerin gelişiminin temelinin karakterimizin gelişimine ve derinliğine bağl1 olduğunu öğrenmektir.

- Okul kültürü temellidir.

- Sadece bir program değil, bir süreçtir.

- En iyi anlatımla kapsamlı bir okul reformudur.

- Araştırmalar, teoriler ve en önemlisi öğretmen ve öğrenci katılımı hakkında bilgi vermelidir.

- Öğretmen ve öğrenci olarak herkesin içindeki en iyiyi ortaya çıkarır.

Okul ortamı, özellikle de ilkokul ve ortaokul dönemi karakter gelişimi açısından oldukça önemlidir. Ergenlik döneminin ortaokul çağına denk geldiği ve çocukluk döneminin bir devamı olarak düşünüldügünde ilkokul ve ortaokul döneminin karakter eğitiminde büyük bir öneme sahip olduğu söylenebilir (Yalız, 2011). Bu araştırma ortaokul öğretim programlarındaki kazanımların karakter eğitimi ile ne düzeyde ilişkili olduğunun incelenmesi açısından önemli bir çalışmadır. Türkiye'de bu alandaki çalışmaların oldukça sınırlı olduğu gerçeği göz önüne alınarak araştırmanın alana katkı sağlayacağı düşünülmektedir. $\mathrm{Bu}$ çalışma ile öğretim programlarındaki kazanımların karakter eğitimi ile ilişkisi belirlenerek bu ilişki ilerde hazırlanacak programlara 1şık tutabilir.

\section{Araştırmanın Amacı}

$\mathrm{Bu}$ araştırmanın amacı ortaokulda okutulan derslerin öğretim programlarına ait kazanımların karakter eğitimini ne ölçüde desteklediğini belirlemektir. Bu amaç doğrultusunda aşağıdaki sorulara yanıt aranmıştır.

1. Türkçe

2. Sosyal Bilgiler

3. Fen Bilimleri 
4. Din Kültürü ve Ahlak Bilgisi

5. T.C. İnkılap Tarihi ve Atatürkçülük

6. Rehberlik ve Kariyer Planlama

7. Beden Eğitimi ve Spor

dersi programlarına ait kazanımların ne kadarı karakter eğitimi ile ilişkilidir?

\section{Yöntem}

\section{Araştırmanın Modeli}

$\mathrm{Bu}$ araştırmada ortaokul öğretim programlarına ait kazanımların belirlenmesinde nitel araştırma tekniklerinden biri olan doküman analizi tekniği kullanılmıştır. Araştırmada bulgular betimsel tarama modeli ile yorumlanmıştır.

\section{Çalışma Grubu}

Araştırmada örneklemin belirlenmesinde nitel araştırmada örneklem seçimi yöntemlerinden amaçlı örneklem kullanılmıştır. Araştırmanın evrenini, Talim ve Terbiye Kurulu Başkanlığı tarafından kabul edilen ortaokuldaki bütün derslerin öğretim programları oluşturmaktadır. Örneklemi ise ortaokul seviyesinde Sosyal Bilgiler, Türkçe, Fen Bilimleri, Din Kültürü ve Ahlak Bilgisi, T.C. İnk1lap Tarihi ve Atatürkçülük, Rehberlik ve Kariyer Planlama, Beden Eğitimi ve Spor derslerinin öğretim programları oluşturmaktadır. Araştırmada çalışma grubu olarak zorunlu derslerden karakter eğitiminin yer aldığı dersler seçilmiştir.

\section{Verilerin Toplanmasi}

Verilerin elde edilmesi sürecinde ilköğretim programlarındaki kazanımlar derslere ve sınıf seviyelerine göre gruplandırılmıştır. Araştırmada 2015-2016 eğitim öğretim yılında okutulan zorunlu derslere ait güncel öğretim programları esas alınmıştır.

\section{Verilerin Analizi}

Araştırma için öncelikle karakterin ne anlama geldiği ve hangi özelliklerin karakter eğitiminin odağı olabileceği (Almerico, 2014) tespit edilerek öğretim programlarının karakter eğitimiyle ilişkisinin incelenmiştir. Araştırma literatüründe karakter özellikleri ve başarılı karakter gelişim programları incelenmiştir 
(Almerico, 2014). Öğretim programlarının analizinde kullanılmak üzere Bulach ve Butler'in (2002) belirlediği 16 temel karakter değeri ele alınmıştır. Bunlar; kendine, başkalarına ve eşyaya saygı, alçakgönüllülük, öz-denetim/disiplin, dürüstlük, sorumluluk/güvenilirlik/hesap verebilirlik, sabır/ilgi, işbirliği, bütünlük/adalet merhamet/empati, affetme, vatanseverlik/vatandaşlık, iyimserlik, hoşgörü, kibarlık/nezaket, cömertlik/yardımseverlik ve sportmenliktir. Bulach ve Butler'in (2002) karakter değerlerine, alan yazın incelemesi sonunda sevgi, duyarlılık ve liderlik özellikleri de eklenerek 19 karakter değeri ele alınmıştır. Her dersin öğretim programında yer alan kazanımlar incelenerek bunların karakter eğitimiyle ilişkili olup olmadığ belirlenmiştir.

\section{Bulgular}

Araştırmanın bu bölümünde elde edilen bulgulara yer verilmiş ve bulgular, araştırmanın alt problemleri doğrultusunda tablo haline getirilerek incelenmiştir.

\section{Türkçe Dersi Öğretim Programındaki Temalar ve Karakter Eğitimi}

Bu başlık altında Türkçe Dersi ortaokul programına ait öğrenme alanlarına ve karakter eğitimi ile ilgili kazanımlara yer verilmiştir.

Türkçe Dersi (5) Öğretim Programı, dinleme, konuşma, okuma, yazma, görsel okuma ve görsel sunu olmak üzere toplam beş öğrenme alanından oluşmaktadır. Öğretim Programı dördü zorunlu, dördü seçmeli olmak üzere sekiz temadan oluşmaktadır. Zorunlu temalar; "Atatürk", "Değerlerimiz", "Sağlık ve Çevre", "Birey ve Toplum" olarak yer almaktadır. Diğer dört tema ise seçmeli temalar arasından seçilebilir. Seçmeli temalar "Güzel Ülkem Türkiye", "Yenilikler ve Gelişmeler”, “Oyun ve Spor”, "Dünyamız ve Uzay”, "Üretim, Tüketim ve Verimlilik", "Hayal Gücü", "Eğitsel ve Sosyal Etkinlikler", "Kurumsal ve Sosyal Örgütler", "Doğal Afetler", "Güzel Sanatlar".

Türkçe Dersi (6-8) Öğretim Program1, "okuma, dinleme/izleme, konuşma, yazma öğrenme alanları ile dil bilgisi” öğrenme alanlarından oluşmaktadır. Her bir öğrenme alanı kapsamında 6, 7 ve 8. sınıf düzeylerine göre özel kazanımlara yer verilmektedir. 6. sinıfta "Sevgi”, 7. sinıfta "Millî Kültür", 8. sinıfta "Toplum Hayatı" zorunlu ana temalardır. Diğer temalar ise şunlardır: "Okuma Kültürü”, "İletişim”, "Hak ve Özgürlükler”, "Kişisel Gelişim”, "Bilim ve Teknoloji”, “Alışkanlıklar", "Zaman ve Mekân”, "Duygular”, "Doğa ve Evren”, "Güzel Sanatlar”, "Kavramlar ve Çağrışımlar”. 
Türkçe Dersi programında sınıf düzeylerine göre kazanımlar ve bu kazanımların karakter eğitimi ile ilişkisi Tablo 1'de özetlenmiştir.

\begin{tabular}{lll}
\hline \multicolumn{2}{l}{ Tablo 1: Türkçe Dersi Ortaokul Programı ve Karakter Eğitimi } \\
\hline Sinıf Düzeyi & Kazanım Sayısı & Karakter Eğitimi ile İlgili Kazanım Sayısı \\
\hline 5. Sınıf & 262 & 13 \\
\hline 6, 7 ve 8. Sınıf & 234 & 4 \\
\hline Toplam & 496 & 17 \\
\hline
\end{tabular}

Tablo 1 incelendiğinde Türkçe Dersi ortaokul programında toplam 496 kazanım bulunmakta ve bu kazanımların sadece 17'sinin (\%3) karakter eğitimi ile ilgili olduğu görülmektedir. Programda beşinci sınıf düzeyinde 262 kazanım bulunduğu ve bu kazanımların 13’ünün (\%5) karakter eğitimi ile ilgili olduğu belirlenmiştir. 6, 7 ve 8. sınıflarda toplam 234 kazanım bulunmakta ve bu kazanımların sadece 4'ünün (\%2) karakter eğitimi ile ilgili olduğu görülmektedir. 6, 7 ve 8. sınıf düzeylerinde kazanımlara ayrı ayrı sınıflar bazında yer verilmemiş olup kazanımlar öğrenme alanları başlıkları altında toplanmıştır. Beşinci sınıf programındaki kazanımlar saygı, öz-denetim/disiplin, işbirliği ve vatandaşlık/vatanseverlik ve duyarlılık karakter değerleri ile ilişkilidir. 6, 7 ve 8. sınıflarda ise sayg1, kibarlık/nezaket ve sabır değerleri ile ilişkilidir. Karakter özellikleri örnekleri;

- $\quad$ sayg1, kibarl1k/nezaket ve sabır; “Konuşmacının sözünü kesmeden sabır ve sayglyla dinler"

- kibarlık/nezaket; "Başkalarını rahatsız etmeden dinler/izler"

"Konuşmasında nezaket kurallarını uyar"

“Konuşmasını belirlenen sürede ve teşekkür cümleleriyle sona erdirir."

Programda daha çok özel alan kazanımlarına yer verilirken karakter eğitimi ile ilgili kazanım sayısı oldukça düşüktür.

\section{Sosyal Bilgiler Dersi Öğretim Programındaki Temalar ve Karakter Eğitimi}

Bu başlık altında Sosyal Bilgiler dersi öğretim programına ait kazanımların karakter eğitimiyle ilişkisine yer verilmiştir.

Sosyal Bilgiler dersi ortaokullar için 5, 6 ve 7. sınıflarda okutulmaktadır. 5. sınıf düzeyinde sekiz öğrenme alanı, 6 ve 7. sınıflar düzeyinde ise yedi öğrenme alanı bulunmaktadır. 5. sınıf düzeyindeki "Gruplar, Kurumlar ve Sosyal Örgütler” öğrenme alanı dışında 5, 6 ve 7. sınıflarda bütün sınıf seviyelerindeki 
öğrenme alanları aynıdır. Bu öğrenme alanları şunlardır: "Birey ve Toplum", "Kültür ve Miras", "İnsanlar, Yerler ve Çevreler”, "Üretim, Dağıtım ve Tüketim”, "Bilim, Teknoloji ve Toplum”, “Güç, Yönetim ve Toplum”, ve "Küresel Bağlantılar”. Her bir öğrenme alanı kapsamında olmak üzere 5. sınıflarda yedi ünite, 6 ve 7. Sinıflarda ise sekiz ünite yer almaktadır.

Sosyal Bilgiler ortaokul (5-7) dersi programındaki öğrenme alanlarına ait kazanımlar ve bu kazanımların karakter eğitimi ile ilişkisi Tablo 2'de özetlenmiştir.

\begin{tabular}{|c|c|c|c|c|}
\hline Öğrenme Alanı & $\begin{array}{l}\text { Sinıf } \\
\text { Düzeyi }\end{array}$ & Ünite & $\begin{array}{l}\text { Kazanım } \\
\text { Sayısı }\end{array}$ & $\begin{array}{l}\text { Karakter Eğitimi ile } \\
\text { İlgili Kazanım Sayısı }\end{array}$ \\
\hline \multirow{3}{*}{ Birey ve Toplum } & 5 & Haklarımı Öğreniyorum & 4 & 4 \\
\hline & 6 & Sosyal Bilgiler Öğreniyorum & 6 & 2 \\
\hline & 7 & İletişim ve İnsan İlişkileri & 6 & 4 \\
\hline \multirow{3}{*}{ Kültür ve Miras } & 5 & Adım Adım Türkiye & 6 & 3 \\
\hline & 6 & İpek Yolu'nda Türkler & 9 & 2 \\
\hline & 7 & Türk Tarihinde Yolculuk & 8 & 4 \\
\hline \multirow{3}{*}{$\begin{array}{l}\text { İnsanlar, Yerler ve } \\
\text { Çevreler }\end{array}$} & 5 & Bölgemizi Tanıyalım & 8 & 1 \\
\hline & 6 & Yeryüzünde yaşam & 7 & 2 \\
\hline & 7 & Ülkemizde Nüfus & 5 & 1 \\
\hline \multirow{3}{*}{$\begin{array}{l}\text { Üretim, Dağıtım ve } \\
\text { Tüketim }\end{array}$} & 5 & Ürettiklerimiz & 7 & 2 \\
\hline & 6 & Ülkemizin Kaynakları & 6 & 3 \\
\hline & 7 & Ekonomi ve Sosyal Hayat & 6 & 1 \\
\hline \multirow{3}{*}{$\begin{array}{l}\text { Bilim, Teknoloji ve } \\
\text { Toplum }\end{array}$} & 5 & Gerçekleşen Düşler & 6 & 1 \\
\hline & 6 & Elektronik Yüzyıl & 5 & 2 \\
\hline & 7 & Zaman İçinde Bilim & 5 & 1 \\
\hline $\begin{array}{l}\text { Gruplar, Kurumlar ve } \\
\text { Sosyal Örgütler }\end{array}$ & 5 & Toplum İçin Çalışanlar & 5 & 2 \\
\hline \multirow{3}{*}{$\begin{array}{l}\text { Güç, Yönetim ve } \\
\text { Toplum }\end{array}$} & 5 & Bir Ülke Bir Bayrak & 5 & 3 \\
\hline & 6 & Demokrasinin Serüveni & 5 & 4 \\
\hline & 7 & Yaşayan Demokrasi & 5 & 4 \\
\hline \multirow{3}{*}{ Küresel Bağlantılar } & 5 & Hepimizin Dünyası & 6 & 2 \\
\hline & 6 & Ülkemiz ve Dünya & 5 & 2 \\
\hline & 7 & Ülkelerarası Köprüler & 4 & 2 \\
\hline Toplam & & & 129 & 52 \\
\hline
\end{tabular}

Tablo 2 incelendiğinde Sosyal Bilgiler dersi öğretim programında ortaokul düzeyinde toplam 129 kazanım yer almakta ve bu kazanımların 52'sinin (\%40) karakter eğitimi ile ilgisi bulunmaktadır. Her ünitede karakter eğitimi ile ilgili en az bir kazanıma yer verildiği görülmektedir. Karakter eğitimi ile ilgili kazanımların öğrenme alanlarına dağılımı incelendiğinde en çok sayıda kazanıma yer verilen öğrenme alanı "Güç, Yönetim ve Toplum", en az sayıda kazanımın bulunduğu öğrenme alanı ise "Gruplar, Kurumlar ve Sosyal Örgütler" olarak tespit edilmiştir. Ayrıca karakter eğitimi ile ilgili kazanımların sınıf seviyelerine dağılımına bakıldığında yaklaşık olarak eşit dağılım gerçekleştiği görülmektedir. 
Programda karakter eğitimi ile ilişkili kazanımlar incelendiğinde kazanımların ağırlıklı olarak vatandaşlık/vatanseverlik, sorumluluk ve adalet karakter değerleri ile ilişkili olduğu belirlenmiştir. Karakter eğitimi ile ilgili diğer kazanımlar ise hoşgörü, duyarlılık, dürüstlük, sayg1, öz-denetim/disiplin değerleri ile ilgilidir. Karakter özelliklerinden örnekler;

- $\quad$ vatandaşl1k/vatanseverlik; "Vatandaşlık sorumluluğu ve ülke ekonomisine katkısı açısından vergi vermenin gereğini ve önemini savunur"

- $\quad$ adalet; “Tarihsel belgelerden yola çıkarak insan haklarının gelişim sürecini analiz eder"

- $\quad$ sorumluluk; "Küresel sorunların çözümlerinin yaşama geçirilmesinde kişisel sorumluluğunu fark eder"

- hoşgörü; "Osmanlı toplumunda hoşgörü ve birlikte yaşama fikrinin önemine dayalı kanitlar gösterir"

- dürüstlük; "Telif ve patent haklarl sakl ürünlerin yasal yollardan temin edilmesinin gerekliliğini savunur"

- duyarlılık; "Doğal kaynakların bilinçsizce tüketilmesinin insan yaşamına etkilerini tartışır"

- $\quad$ öz-denetim/disiplin; "İletişimi, olumlu olumsuz etkileyen tutum ve davranışları fark ederek kendi tutum ve davranışlarılla karşılaştırır"

- $\quad$ sayg1; "Kitle iletişim özgürlüğü ve özel hayatın gizliliği kavramlarını, birbiriyle ilişkileri çerçevesinde yorumlar"

\section{Fen Bilimleri Dersi Öğretim Programındaki Temalar ve Karakter Eğitimi}

Bu başlık altında Fen Bilimleri dersi (5, 6, 7 ve 8. sınıflar) öğretim programına ait kazanım, öğrenme alanları ve ünitelerin karakter eğitimiyle ilişkisine yer verilmiştir.

Fen Bilimleri Dersi Öğretim Programında, tüm öğrencilerin fen okuryazarı olması vizyonunun gerçekleştirilebilmesi için "Bilgi” öğrenme alanına ait "Canlılar ve Hayat", "Madde ve Değişim", "Fiziksel Olaylar" ve "Dünya ve Evren" konu alanları ile "Beceri", "Duyuş", "Fen-Teknoloji-Toplum-Çevre (FTTÇ)" öğrenme alanları belirlenmiştir "Beceri” öğrenme alanı, "Bilimsel Süreç Becerileri" ve "Yaşam Becerileri” alt öğrenme alanlarından, "Duyuş" öğrenme 
alanı "Tutum", "Motivasyon", ,Değer" ve "Sorumluluk" alt öğrenme alanlarından, "Fen-Teknoloji-Toplum-Çevre (FTTÇ)" öğrenme alanı, "Sosyo-Bilimsel Konular", "Bilimin Doğası”, "Bilim ve Teknoloji İlişkisi”, "Bilimin Toplumsal Katkısı", "Sürdürülebilir Kalkınma" ve "Fen ve Kariyer Bilinci" alt öğrenme alanlarından oluşmaktadır.

Ortaokul 5, 6, 7 ve 8. sınıflar Fen Bilimleri dersi öğretim programında ünitelere göre kazanımlar ve bu kazanımların karakter eğitimi ile ilişkisi Tablo 3 ’te özetlenmiştir.

Tablo 3: Ortaokul Fen Bilimleri Dersi Öğretim Programı ve Karakter Eğitimi

\begin{tabular}{|c|c|c|c|c|}
\hline $\begin{array}{l}\text { Öğrenme } \\
\text { Alanı }\end{array}$ & $\begin{array}{l}\text { Sınıf } \\
\text { Düzeyi }\end{array}$ & Ünite Başlıkları & $\begin{array}{l}\text { Kazanım } \\
\text { Sayısı }\end{array}$ & $\begin{array}{l}\text { Karakter Eğitimiyle } \\
\text { İlgili Kazanım Sayısı }\end{array}$ \\
\hline \multirow{8}{*}{$\begin{array}{l}\text { Canlilar ve } \\
\text { Hayat }\end{array}$} & 5 & Vücudumuzun Bilmecesini Çözelim & 13 & 5 \\
\hline & 5 & $\begin{array}{l}\text { Canlılar Dünyasını Gezelim ve Tanı- } \\
\text { yalım }\end{array}$ & 3 & 2 \\
\hline & 6 & Vücudumuzdaki Sistemler & 14 & 3 \\
\hline & 6 & $\begin{array}{l}\text { Bitki ve Hayvanlarda Üreme, Büyüme } \\
\text { ve Gelişme }\end{array}$ & 4 & - \\
\hline & 7 & Vücudumuzdaki Sistemler & 16 & 6 \\
\hline & 7 & İnsan ve Çevre İlişkileri & 4 & 2 \\
\hline & 8 & İnsanda Üreme, Büyüme ve Gelişme & 13 & - \\
\hline & 8 & Canlılar ve Enerji İlişkileri & 11 & 3 \\
\hline \multirow{12}{*}{$\begin{array}{l}\text { Fiziksel } \\
\text { Olaylar }\end{array}$} & 5 & Kuvvetin Büyüklüğünün Ölçülmesi & 2 & - \\
\hline & 5 & Işığın ve Sesin Yayılması & 7 & - \\
\hline & 5 & Yaşamımızın Vazgeçilmezi: Elektrik & 3 & - \\
\hline & 6 & Kuvvet ve Hareket & 6 & - \\
\hline & 6 & Işık ve Ses & 5 & - \\
\hline & 6 & Elektriğin İletimi & 5 & - \\
\hline & 7 & Kuvvet ve Enerji & 9 & - \\
\hline & 7 & Aynalarda Yansıma ve Işığın Soğrulması & 6 & - \\
\hline & 7 & Elektrik Enerjisi & 12 & 1 \\
\hline & 8 & Basit Makineler & 3 & - \\
\hline & 8 & Işı1k ve Ses & 6 & - \\
\hline & 8 & Yaşamımızdaki Elektrik & 6 & - \\
\hline \multirow{6}{*}{$\begin{array}{l}\text { Madde ve } \\
\text { Değişim }\end{array}$} & 5 & Maddenin Değişimi & 6 & - \\
\hline & 6 & Maddenin Tanecikli Yapısı & 7 & - \\
\hline & 6 & Madde ve Is1 & 7 & 2 \\
\hline & 7 & Maddenin Yapısı ve Özellikleri & 22 & 7 \\
\hline & 8 & Maddenin Yapısı ve Özellikleri & 16 & 1 \\
\hline & 8 & Maddenin Halleri ve Isı & 7 & - \\
\hline
\end{tabular}




\begin{tabular}{lllll}
\hline \begin{tabular}{l} 
Dünya ve \begin{tabular}{l} 
Evren \\
\cline { 2 - 5 }
\end{tabular} \\
\cline { 2 - 5 }
\end{tabular} & $\begin{array}{l}\text { Yerkabuğunun Gizemi } \\
\text { Dünyamı, Ay ve Yaşam Kaynağımız } \\
\text { Güneş }\end{array}$ & 4 & - \\
\cline { 2 - 5 } & 8 & Güneş Sistemi ve Ötesi & 9 & - \\
\hline Toplam & & Deprem ve Hava Olayları & 16 & 1 \\
\hline
\end{tabular}

Tablo 3'te Fen Bilimleri dersi ortaokul programındaki kazanımlar incelendiğinde beşinci sınıf düzeyinde 44 kazanım, altıncı sınıf düzeyinde 52 kazanım yedinci sınıf düzeyinde 78 kazanım, sekizinci sınıf düzeyinde ise 78 kazanım bulunduğu tespit edilmiştir. Ortaokul öğretim programında toplam 252 kazanım yer almaktadır. Mevcut kazanımların 37'si yani yaklaşık \%15'i karakter eğitimi ile ilişkilidir. Karakter eğitimiyle ilişkili bu 37 kazanımdan 16'sı yedinci sınıf düzeyine, 11'i beşinci sınıf düzeyine aittir. Altıncı ve sekizinci sınıflarda ise karakter eğitimi ile ilişkili 5'er kazanım mevcuttur. Karakter eğitimi ile ilgili kazanımların duyarlılık, sorumluluk, cömertlik/yardımseverlik, merhamet/empati, vatandaşlık/vatanseverlik ve saygı (kendisine ve başkalarına) özelliklerine yoğunlaştığı tespit edilmiştir. Karakter özelliklerinden örnekler;

- sorumluluk ve duyarlılık; "İnsan faaliyetleri sonucunda oluşan çevre sorunlarını araştırır ve bu sorunların çözümüne ilişkin önerilerde bulunur.”

- yardımseverlik ve duyarlılık; "Organ bağışı ve organ naklinin toplumsal dayanışma açısından önemini kavrar.,

- merhamet/empati ve cömertlik/yardımseverlik; "Yeniden kullanılabilecek eşyalarını, ihtiyacı olanlara iletmeye yönelik proje geliştirir."

- vatandaşl1k/vatanseverlik, duyarlıl1k ve sorumluluk; "Elektrik enerjisinin bilinçli ve tasarruflu kullanılmasının aile ve ülke ekonomisi bakımından önemini tartışır."

Karakter eğitimi ile ilgili 37 kazanımın 21'i yani yaklaşık \%57'si canlılar ve hayat öğrenme alanına aittir. Madde ve değişim öğrenme alanında karakter eğitimi ile ilgili 10 kazanım, dünya ve evren öğrenme alanında 5 kazanım, fiziksel olaylar öğrenme alanında ise sadece 1 kazanım bulunmaktadır.

\section{Din Kültürü ve Ahlak Bilgisi Dersi Öğretim Programındaki Temalar ve Karakter Eğitimi}

Bu başlık altında Din Kültürü ve Ahlak Bilgisi dersi programına ait kazanımların karakter eğitimiyle ilişkisine yer verilmiştir. 
Din Kültürü ve Ahlak Bilgisi dersi (5, 6, 7 ve 8. Sınıflar) "İnanç, İbadet, Hz. Muhammed, Kur'an ve Yorumu, Ahlak, Din ve Kültür” den oluşan altı öğrenme alanı üzerine yapılandırılmıştır. Her sınıfta, altı öğrenme alanından her biri için bir ünite yer almaktadır.

Din Kültürü ve Ahlak Bilgisi dersi ortaokul $(5,6,7,8$. sinıflar) öğretim programında üniteler ve öğrenme alanlarına göre kazanımlar ve bu kazanımların karakter eğitimi ile ilişkisi Tablo 4'te özetlenmiştir.

\begin{tabular}{|c|c|c|c|c|}
\hline $\begin{array}{l}\text { Öğrenme } \\
\text { Alanı }\end{array}$ & $\begin{array}{l}\text { Sınıf } \\
\text { Düzeyi }\end{array}$ & Ünite Başlıkları & $\begin{array}{l}\text { Kazanım } \\
\text { Sayısı }\end{array}$ & $\begin{array}{l}\text { Karakter } \\
\text { Eğitimiyle İl- } \\
\text { gili Kazanım } \\
\text { Sayısı }\end{array}$ \\
\hline \multirow[t]{4}{*}{ İnanç } & 5 & Allah İnanc1 & 7 & - \\
\hline & 6 & Peygamberlere ve İlahi Kitaplara İnanç & 10 & 1 \\
\hline & 7 & Melek ve Ahiret İnanc1 & 14 & 2 \\
\hline & 8 & Kaza ve Kader & 9 & 2 \\
\hline \multirow[t]{4}{*}{ İbadet } & 5 & İbadet Konusunda Bilgilenelim & 12 & 2 \\
\hline & 6 & Namaz İbadeti & 11 & 2 \\
\hline & 7 & Oruç İbadeti & 10 & 1 \\
\hline & 8 & Zekât, Hac ve Kurban İbadeti & 11 & 8 \\
\hline \multirow{4}{*}{$\begin{array}{l}\mathrm{Hz} . \mathrm{Mu}- \\
\text { hammed }\end{array}$} & 5 & Hz. Muhammed ve Aile Hayatı & 5 & 3 \\
\hline & 6 & Son Peygamber Hz. Muhammed & 11 & 3 \\
\hline & 7 & Bir İnsan ve Peygamber Olarak Hz. Muhammed & 7 & 1 \\
\hline & 8 & Hz. Muhammed'in hayatından Örnek Davranışlar & 5 & 5 \\
\hline \multirow{4}{*}{$\begin{array}{l}\text { Kur'an ve } \\
\text { Yorumu }\end{array}$} & 5 & Kur'an-1 Kerim'in Temel Eğitici Nitelikleri & 6 & 1 \\
\hline & 6 & Kur'an-1 Kerim'in Ana Konuları & 5 & 1 \\
\hline & 7 & İslam Düşüncesinde Yorumlar & 8 & 2 \\
\hline & 8 & Kur'an'da Ak1l ve Bilgi & 6 & 2 \\
\hline \multirow[t]{4}{*}{ Ahlak } & 5 & Sevinç ve Üzüntülerimizi Paylaşalım & 9 & 6 \\
\hline & 6 & İslam'ın Sakınılmasını İstediği Bazı Davranışlar & 6 & 5 \\
\hline & 7 & Din ve Güzel Ahlak & 5 & 5 \\
\hline & 8 & İslam Dinine Göre Kötü Alışkanlıklar & 6 & 6 \\
\hline \multirow{4}{*}{$\begin{array}{l}\text { Din ve } \\
\text { Kültür }\end{array}$} & 5 & Vatanımızı ve Milletimizi Seviyoruz & 8 & 8 \\
\hline & 6 & İslamiyet ve Türkler & 4 & 1 \\
\hline & 7 & Kültürümüz ve Din & 6 & 5 \\
\hline & 8 & Dinler ve Evrensel Öğütleri & 7 & 2 \\
\hline Toplam & & & 188 & 74 \\
\hline
\end{tabular}

Tablo 4 incelendiğinde Ortaokul Din Kültürü ve Ahlak Bilgisi Dersi Programında toplam 188 kazanım yer almaktadır. Bu kazanımların 74'ü (\%39) karakter eğitimi ile doğrudan ilişkilidir. Öğrenme alanlarına göre karakter eğitimi ile ilgili kazanım sayıları incelendiğinde en çok kazanımın bulunduğu öğrenme 
alanının 22 kazanımla (\%30) "Ahlak" öğrenme alanı olduğu görülmektedir. “İbadet” öğrenme alanından 13 kazanım, "Hz. Muhammed” öğrenme alanından 12 kazanım, "Din ve Kültür" öğrenme alanından 16 kazanım, "Kur'an ve Yorumu" öğrenme alanından ise 6 kazanım karakter eğitimi ile ilişkilidir. Karakter eğitimi ile ilgili en az kazanıma sahip olan öğrenme alanı ise "İnanç" $(\mathrm{f}=5)$ öğrenme alanıdır.

Tablo 4 sınıf düzeyleri bakımından incelendiğinde beşinci sınıf düzeyinde 47 kazanımdan 20'sinin (\%43), altıncı sınıf düzeyinde 47 kazanımdan 13'ünün (\%28), yedinci sınıf düzeyinde 50 kazanımdan 16 'sının (\%32) ve sekizinci s1nıf düzeyinde 44 kazanımdan 25'inin (\%57) karakter eğitimi ile ilgili olduğu görülmektedir. Din Kültürü ve Ahlak Bilgisi Dersi ortaokul programında vatandaşlık/vatanseverlik, sevgi, saygı, merhamet/empati, hoşgörü, iyimserlik, yardımseverlik, sorumluluk, sabır, bütünlük/adalet, öz-denetim/disiplin ve duyarlılık karakter değerleri ile ilgili kazanımlara yer verildiği belirlenmiştir. Karakter özelliklerinden örnekler;

- $\quad$ sevgi ve duyarlılık; "Hz. Muhammed'in doğa ve hayvan sevgisiyle ilgili davranışlarına örnekler vererek doğayı ve hayvanları koruma konusunda duyarlı olur."

- vatandaşlık/vatanseverlik ve sayg1; "Bayrağa ve ulusal marşa saygl göstermenin nedenlerini açıklayarak Bayrağımıza ve İstiklâl Marşı 'mıza saygı gösterir."

- öz denetim/disiplin; "Sakınılması gereken davranışlar konusunda öz değerlendirmede bulunur."

- hoşgörü; "Farklı din ve inançlara hoşgörülü olur."

- $\quad$ sabır; "Hz. Eyyüp kıssasından hareketle sabrın güçlükler ve olumsuzlukları aşmadaki rolünü açılar.”

- merhamet/empati, sevgi ve yardımseverlik; "Toplumdaki engellilere sevgi ile bakar ve onların sorunlarına çözüm önerileri gelişsirir.”

Ortaokul programında karakter eğitimi ile ilişkili kazanımların toplam kazanımlara oranına bakıldığında ise en yüksek oranın \%57 ile sekizinci sınıf programına, en düşük oranın ise \%28 ile altıncı sınıf programına ait olduğu belirlenmiştir. Programdaki öğrenme alanlarının karakter eğitimi ile ilişkisi göz önüne alındığında ise "Ahlak" öğrenme alanı ilk sırada yer almaktadır. Karakter eğitim ile ilişkili kazanımların \%30’unu "Ahlak” öğrenme alanı oluşturmaktadır. 
Ayrıca ortaokul programlarında karakter eğitimine ilişkin kazanımlar incelendiğinde 5. sınıf programında "İnanç" öğrenme alanına ait herhangi bir kazanıma yer verilmediği tespit edilmiştir.

\section{Türkiye Gumhuriyeti İnkılap Tarihi ve Atatürkçülük Dersi Öğre- tim Programındaki Temalar ve Karakter Eğitimi}

Bu başlık altında Türkiye Cumhuriyeti İnkılap Tarihi ve Atatürkçülük dersi programına ait kazanım, kavram ve becerilerin karakter eğitimiyle ilişkisine yer verilmiştir.

Türkiye Cumhuriyeti İnkılap Tarihi ve Atatürkçülük dersi ortaokul 8. sınıf düzeyinde hazırlanmıştır. 7. ve 8. sınıflardaki İnsan Hakları ve Vatandaşlık dersi ilköğretim 1. sınıftan itibaren bir ara disiplin olarak ele alınmış, insan hakları ve vatandaşlık kazanımlarına Sosyal Bilgiler dersi öğretim programında da yer verilmiştir. TC İnkılap Tarihi ve Atatürkçülük dersi 7 ünite olarak hazırlanmıştır.

TC İnkılap Tarihi ve Atatürkçülük dersi ortaokul 8. sınıf öğretim programında ünitelere göre kazanımlar ve bu kazanımların karakter eğitimi ile ilişkisi Tablo 5 'te özetlenmiştir.

Tablo 5: TC İnkılap Tarihi ve Atatürkçülük Dersi Öğretim Programı ve Karakter Eğitimi

\begin{tabular}{llll}
\hline $\begin{array}{l}\text { Sıra } \\
\text { No }\end{array}$ & Ünite & $\begin{array}{l}\text { Kazanım } \\
\text { Sayısı }\end{array}$ & $\begin{array}{l}\text { Karakter Eğitimi } \\
\text { ile İlgili Kazanım } \\
\text { Sayısı }\end{array}$ \\
\hline 1 & Bir Kahraman Doğuyor & 6 & 1 \\
\hline 2 & Milli Uyanış: Yurdumuzun İşgaline Tepkiler & 8 & 3 \\
\hline 3 & Ya İstiklal Ya Ölüm & 7 & - \\
\hline 4 & Çağdaş Türkiye Yolunda Adımlar & 25 & 7 \\
\hline 5 & Atatürkçülük & 17 & 4 \\
\hline 6 & Atatürk Dönemi Türk Dış Politikası ve Atatürk' ün Ölümü & 5 & 2 \\
\hline 7 & Atatürk' ten Sonra Türkiye: İkinci Dünya Savaşı ve Sonrası & 12 & 3 \\
\hline Toplam & 80 & 20 \\
\hline
\end{tabular}

Tablo 5 incelendiğinde İnkılap Tarihi ve Atatürkçülük dersi programında 80 kazanım bulunduğu tespit edilmiştir. Mevcut kazanımların 20'si (\%25) doğrudan karakter eğitimi ile ilişkilidir. Karakter eğitimiyle ilgili en çok kazanıma ( $\mathrm{f}=7, \% 35)$ "Çağdaş Türkiye Yolunda Adımlar" ünitesinde yer verilmiştir. "Ya İstiklal Ya Ölüm” ünitesinde ise karakter eğitimi ile ilgili herhangi bir kazanıma yer verilmemiştir.

TC İnkılap Tarihi ve Atatürkçülük dersi programında karakter eğitimi ile doğrudan ilişkili kazanımlar incelendiğinde; vatanseverlik/vatandaşlık, sorumlu- 
luk, adalet, liderlik, iş birliği, duyarlılık karakter değeri ile ilgili kazanımlara yer verildiği belirlenmiştir. Karakter özelliklerinden örnekler:

- vatanseverlik/vatandaşl1k; "Bir Türk vatandaşı olarak cumhuriyetin Türk milletine kazandırdiğl vatandaşlık temel hak ve sorumlulukları bilincini kazanır."

- adalet; "Millî egemenlik, eşitlik, adalet, demokratik hak kavramların Atatürkçü düşünce sistemindeki halkçıllk ilkesi ile ilişkilendirir."

- liderlik; "Mustafa Kemal'in Millî Mücadeleyi örgütlerken karşılaş̧tı̆̆ sorunlara bulduğu çözüm yollarını, onun liderlik yeteneği ile ilişkilendirir."

- duyarlılık; “Türkiye Cumhuriyeti'nin temel niteliklerine yönelik iç ve dış tehditlere karşı korunması konusunda duyarlı olur."

- sorumluluk; "Atatürk ilke ve inkılaplarına sahip çıkma ve devamlılığını sağlama konusunda kişisel sorumluluk alır."

\section{Rehberlik ve Kariyer Planlama Dersi Öğretim Programındaki Temalar ve Karakter Eğitimi}

Bu başlık altında 8. sınıf Rehberlik ve Kariyer Planlama dersi öğretim prograf mına ait kazanımların karakter eğitimiyle ilişkisine yer verilmiştir. Rehberlik ve Kariyer Planlama dersi öğretim programı; "Kendini Tanıma", "Güvenli ve Sağlıklı Yaşam", "Eğitim Yaşamı", "Meslekleri Tanıma” ve "Kariyer Planlama" olmak üzere toplam 5 konu alanından oluşmaktadır.

Rehberlik ve Kariyer Planlama dersi 8. sinıf programındaki konu alanlarına ait kazanımlar ve bu kazanımların karakter eğitimi ile ilişkisi Tablo 6' da özetlenmiştir.

Tablo 6: Rehberlik ve Kariyer Planlama Dersi Öğretim Programı ve Karakter Eğitimi

\begin{tabular}{llll}
\hline Sıra No & Konular & Kazanım Sayısı & Karakter Eğitimiyle İlgili Kazanım Sayısı \\
\hline 1 & Kendini Tanıma & 9 & 5 \\
\hline 2 & $\begin{array}{l}\text { Güvenli ve Sağlıklı } \\
\text { Yaşam }\end{array}$ & 6 & 5 \\
\hline 3 & Eğitim Yaşamı & 6 & 2 \\
\hline 4 & Meslekleri Tanıma & 14 & 1 \\
\hline 5 & Kariyer planlama & 9 & 1 \\
\hline Toplam & & 44 & 14 \\
\hline
\end{tabular}

Tablo 6 Rehberlik ve Kariyer Planlama dersi öğretim programında toplam 44 kazanıma yer verilmiştir ve bu kazanımların 14'ü (\%32) karakter eğitimi ile ilişkilidir. Karakter eğitimi ile ilgili kazanımların ilişkili olduğu karakter değer- 
leri ise şunlardır; öz-denetim/disiplin, saygı, sabır/ilgi, sorumluluk, vatandaşlık/ vatanseverlik ve hoşgörü. Karakter özelliklerinden örnekler;

- öz-denetim/disiplin; "Stresle başa çıkmada uygun yöntemler kullanır."

- saygı (kendine); "Güvenli ve sağllklı hayat için gerekli alışkanlıkları edinir."

• sorumluluk; "Okuldaki görev ve sorumlulukların yerine getirir."

- sabır/ilgi; "Okul başarısını arttırmak için planlı çalışmaya özen gösterir."

Konu alanlarına göre karakter eğitimi ile ilgili kazanım sayısına bakıldığında karakter eğitimi ile ilgili en az kazanımın ( $\mathrm{f}=1$ ), en çok kazanıma sahip olan "Meslekleri Tanıma" konu alanına ( $\mathrm{f}=14$ ) ait olduğu görülmektedir. "Güvenli ve Sağlıklı Yaşam" konu alanı kazanımlarının ( $\mathrm{f}=6)$ ise nerdeyse tamamının $(\mathrm{f}=5)$ karakter eğitimi ile ilgili olduğu tespit edilmiştir.

\section{Beden Eğitimi ve Spor Dersi Öğretim Programındaki Temalar ve Karakter Eğitimi}

Bu başlık altında Beden Eğitimi ve Spor dersi programına ait kazanımların karakter eğitimiyle ilişkisine yer verilmiştir.

Beden Eğitimi ve Spor dersi ilkokullardaki Oyun ve Fiziki Etkinlikler dersinin ortaokullardaki devamıdır. Bu doğrultuda Beden Eğitimi ve Spor Dersi Öğretim Programı, ortaokul 5-8. Sınıflar düzeyindeki öğrencilerin gelişim ihtiyaçları ve eğitim öncelikleri göz önüne alınarak "hareket yetkinliği" ve "aktif ve sağlıklı yaşam” olmak üzere iki temel öğrenme ve gelişim alanı üzerine tasarlanmıştır. Aynı zamanda, "beden eğitimi ve spor" etkinliklerinin içindeki öz-yönetim, sosyal ve düşünme becerilerini geliştirme firsatlarından etkili bir şekilde yararlanmak için bu boyutlarla ilgili kazanımlara da öğretim programında yer verilmiştir.

Ortaokul 5-8. Sınıflar Beden Eğitimi ve Spor dersi programındaki öğrenme alanlarına ait kazanımlar ve bu kazanımların karakter eğitimi ile ilişkisi Tablo 7'de özetlenmiştir.

Tablo 7: Beden Eğitimi ve Spor Dersi Öğretim Programı ve Karakter Eğitimi

\begin{tabular}{llll}
\hline Öğrenme Alanı & $\begin{array}{l}\text { Sınıf } \\
\text { Düzeyi }\end{array}$ & $\begin{array}{l}\text { Kazanım } \\
\text { Sayısı }\end{array}$ & $\begin{array}{l}\text { Karakter Eğitimi ile İlgili Kaza- } \\
\text { nım Sayısı }\end{array}$ \\
\hline Hareket Yetkinliği & $5 . \sin ı f$ & 18 & 5 \\
\cline { 2 - 4 } & $6 . \operatorname{sinıf}$ & 18 & 6 \\
\cline { 2 - 4 } & $7 . \operatorname{sinıf}$ & 19 & 8 \\
\cline { 2 - 4 } & $8 . \sin ı f$ & 16 & 6 \\
\hline
\end{tabular}




\begin{tabular}{llll}
\hline Aktif ve Sağlıklı Yaşam & \multicolumn{1}{c}{ 5. sinıf } & 12 & 4 \\
\cline { 2 - 4 } & 6. sinıf & 12 & 4 \\
\cline { 2 - 4 } & 7. sinıf & 12 & 4 \\
\cline { 2 - 4 } & 8. sinıf & 12 & 3 \\
\hline Toplam & & 119 & 40 \\
\hline
\end{tabular}

Tablo 7'de Ortaokul Beden Eğitimi ve Spor dersine ait kazanımlar incelendiğinde programda 119 kazanıma yer verildiği ve bu kazanımların 40'ının (\%34) doğrudan karakter eğitimi ile ilgili olduğu tespit edilmiştir. Karakter eğitimi ile ilgili kazanımların; iş birliği, hoşgörü, sorumluluk, saygı, duyarlılık, öz-denetim/disiplin, liderlik, vatandaşlık/vatanseverlik, sportmenlik, yardımseverlik ve bütünlük/adalet karakter değerleri ile ilişkili olduğu tespit edilmiştir. Karakter özelliklerinden örnekler;

- $\quad$ sportmenlik; "Oyun ve etkinliklerde kaybetmeye ve kazanmaya ilişkin uygun davranışlar sergiler."

- $\quad$ saygi; "Sporlara hazırlayıcı oyun ve etkinliklerde başkalarının haklarına saygl gösterir."

- $\quad$ iş birliği; "Sporlara hazırlayıcı oyun ve etkinliklerde işbirliğine dayalı davranışlar gösterir"

- $\quad$ vatandaşlık/vatanseverlik, "Millî bayramlar/belirli gün ve haftalar için hazırlanan etkinliklere istekle katılır."

- hoşgörü; "Sporlara hazırlayıcı oyun ve etkinliklerde meydana gelen anlaşmazlıklar için etkili iletişim yolları kullanır."

- liderlik; "Sporlara hazırlayıcı oyun ve etkinliklerde liderlik becerileri gösterir."

Tablo 7'de sınıf düzeyleri açısından incelendiğinde 5. Sınıf düzeyinde 30 kazanımın 9'unun, 6. Sınıf düzeyinde 30 kazanımın 10'unun, 7. Sınıf düzeyinde 31 kazanımın 12'sinin, 8. Sınıf düzeyinde 28 kazanımın 9'unun karakter eğitimi ile doğrudan ilişkili olduğu belirlenmiştir. Böylece karakter eğitimi ile ilgili en çok kazanıma 7.sınıf düzeyinde ( $\mathrm{f}=12)$ yer verildiği görülmektedir. Öğrenme alanları açısından inceleme yapıldığında ise "hareket yetkinliği" öğrenme alanına ait 71 kazanımın 25 'inin, "aktif ve sağlıklı yaşam” öğrenme alanına ait 48 kazanımın ise 15 'inin karakter eğitimi ile ilgili olduğu tespit edilmiştir.

Karakter eğitimi ile ilgili kazanımlar incelendiğinde sınıf düzeyi arttıkça aynı kazanıma genişletilerek yer verildiği görülmektedir. Sınıf seviyelerine göre hoşgörü ve duyarlılık karakter değerleriyle ilişkili şu kazanımlar buna örnek gösterilebilir; 
- 5. sinıf; "Oyun ve etkinliklerde bireysel farklllıklara duyarlı olur."

- 6. sinıf; "Sporlara hazırlayıcı oyun ve etkinliklerde bireysel farklıllğı olanlarla çalışmaya gönüllü olur."

- 7. sinıf; "Sporlara hazırlayıcı oyun ve etkinliklerde bireysel farklılı̆̆ı olanlarla çalışmaya istekli olur."

- 8. sınıf; "Spor ve etkinliklere katılımda bireysel farklılığı olanlarla çalışmaya değer verir."

\section{Ortaokul Programlarının Tamamına İlişkin Bulgular}

Ortaokul öğretim programlarında kazanımların karakter eğitimi ile ilişkisi Tablo 8'de özetlenmiştir.

\begin{tabular}{|c|c|c|c|c|c|}
\hline Sinıf Seviyesi & Dersler & 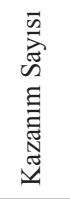 & 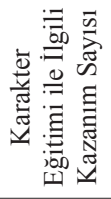 & $\begin{array}{l}\mathbb{N} \\
\vdots \\
\vdots\end{array}$ & 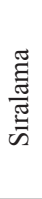 \\
\hline 5-8. Siniflar & Türkçe & 496 & 17 & 3 & 7 \\
\hline 5-7. Siniflar & Sosyal Bilgiler & 129 & 52 & 40 & 1 \\
\hline 5-8. Siniflar & Fen Bilimleri & 252 & 37 & 15 & 6 \\
\hline 5-8. Siniflar & Din Kültürü ve Ahlak Bilgisi & 188 & 74 & 39 & 2 \\
\hline 8. Sinif & İnkılap Tarihi ve Atatürkçülük & 80 & 20 & 25 & 5 \\
\hline 8. Sinif & Rehberlik ve Kariyer Planlama & 44 & 14 & 32 & 4 \\
\hline 5-8. Siniflar & Beden Eğitimi ve Spor & 119 & 40 & 34 & 3 \\
\hline Toplam & & 1308 & 254 & 19 & \\
\hline
\end{tabular}

Tablo 8 incelendiğinde ortaokul öğretim programlarının tamamında karakter eğitimi ile ilgili kazanımların, toplam kazanımların \%19'unu oluşturduğu görülmektedir. Karakter eğitimi ile ilişkisi bakımından ortaokul programları arasında ilk sırada yer alan Sosyal Bilgiler dersi programında karakter eğitimi ile ilgili kazanımların oranının \%40 olduğu belirlenmiştir. Bu dersi sırayla, Din Kültürü ve Ahlak Bilgisi (\%39), Beden Eğitimi ve Spor (\%34), Rehberlik ve Kariyer Planlama (\%32), İnkılap Tarihi ve Atatürkçülük (\%25) ve Fen Bilimleri (\%15) dersleri izlemektedir. Ortaokul öğretim programları arasında kazanım sayısı en yüksek olan Türkçe dersi programının ( $\mathrm{f}=496)$ ise karakter eğitimi ile ilişkisinin en düşük oranda (\%3) olduğu görülmektedir.

Ortaokul öğretim programlarında kazanımlarda yer alan karakter değerlerinin derslere dağılımı Tablo 9'da özetlenmiştir. 
Tablo 9: Ortaokul Programlarında Yer Alan Karakter Değerleri

\begin{tabular}{|c|c|c|c|c|c|c|c|c|}
\hline Karakter Değerleri & $\begin{array}{l}\stackrel{\circlearrowright}{0} \\
\vdots \\
\vdots\end{array}$ & $\begin{array}{l}\frac{\overrightarrow{0}}{\overrightarrow{0} 0} \\
\frac{0}{0} \\
\frac{\pi}{\pi} \\
\frac{\pi}{0} \\
0 \\
\infty\end{array}$ & 竞 & 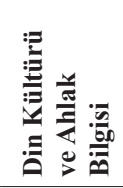 & 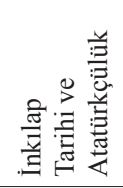 & 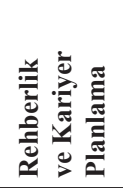 & 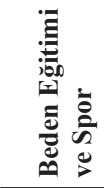 & 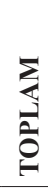 \\
\hline $\begin{array}{l}\text { Kendine, başkalarına ve } \\
\text { mülkiyete saygı }\end{array}$ & + & + & + & + & - & + & + & 6 \\
\hline Dürüstlük & - & + & - & - & - & - & - & 1 \\
\hline Öz-denetim/disiplin & + & + & - & + & - & + & + & 5 \\
\hline $\begin{array}{l}\text { Sorumluluk/Güvenilirlik/ } \\
\text { Hesap verebilirlik }\end{array}$ & - & + & + & + & + & + & + & 6 \\
\hline Bütünlük/Adalet & - & + & - & + & + & - & + & 4 \\
\hline Sabır/İlgi & + & - & - & + & - & + & - & 3 \\
\hline İş birliği & + & - & - & - & + & - & + & 3 \\
\hline Merhamet/Empati & - & - & + & + & - & - & - & 2 \\
\hline İyimserlik & - & - & - & + & - & - & - & 1 \\
\hline Affetme & - & - & - & - & - & - & - & 0 \\
\hline Vatanseverlik/Vatandaşlık & + & + & + & + & + & + & + & 7 \\
\hline Hoşgörü & - & + & - & + & - & + & + & 4 \\
\hline Cömertlik/Yardımseverlik & - & - & + & + & - & - & + & 3 \\
\hline Kibarlık/Nezaket & + & - & - & - & - & - & - & 1 \\
\hline Sportmenlik & - & - & - & - & - & - & + & 1 \\
\hline Alçakgönüllülük & - & - & - & - & - & - & - & 0 \\
\hline Sevgi & - & - & - & + & - & - & - & 1 \\
\hline Duyarlılık & + & + & + & + & + & - & + & 6 \\
\hline Liderlik & - & - & - & - & + & - & + & 2 \\
\hline
\end{tabular}

Tablo 9 incelendiğinde ortaokul öğretim programlarındaki kazanımlarda en çok dersle ilişkisi bulunması bakımından ilk sırada yer alan karakter değerinin vatandaşlık/vatanseverlik değeri olduğu görülmektedir ( $f=7$ ). Sayg1 (kendine, başkalarına ve mülkiyete), sorumluluk/güvenilirlik/hesap verebilirlik ve duyarlılık ( $\mathrm{f}=6)$ değerleri de ortaokul dersleriyle en çok ilişkili karakter değerleri arasında yer almaktadır. Ortaokul dersleriyle en az ilişkili karakter değerlerine bakıldığında alçakgönüllülük ve affetme değerlerinin herhangi bir dersin kazanımlarıyla ilişkisinin bulunmadığı belirlenmiştir. Sevgi, dürüstlük, iyimserlik, kibarlık/nezaket ve sportmenlik değerlerinin ise sadece bir dersle ilgisi bulunmaktadır $(\mathrm{f}=1)$.

\section{Sonuç, Tartışma ve Öneriler}

Araştırmanın bu bölümünde elde edilen bulgulardan ortaya çıkan sonuçlar ve bu sonuçlardan yola çıkılarak karakter eğitimi ile ilgili önerilere yer verilmiştir. 


\section{Sonuç ve Tartışma}

\section{Birinci Alt Probleme İlişkin Sonuç ve Tartışma}

Araştırmanın birinci alt problemi olan; "Türkçe ders programına ait kazanımların karakter eğitimini gerçekleştirme düzeyi nedir?” sorusu doğrultusunda değerlendirme yapılmıştır.

Türkçe dersi programı ortaokul düzeyinde incelendiğinde toplam kazanım sayısı 496, karakter eğitimi ile ilgili kazanım sayısı ise sadece 17'dir (\%3). Sınıf seviyelerine göre yapılan incelemede ise beşinci sınıflarda 262 kazanım bulunmakta ve bu kazanımların 13' ünün (\%5) karakter eğitimi ile ilgili olduğu görülmektedir. Kazanımlarla ilişkili karakter değerlerine bakıldığında ise; ortaokul düzeyinde sayg1, kibarlık/nezaket, sabır, öz denetim/disiplin, işbirliği, vatandaşlık/vatanseverlik ve duyarlılık özelliklerine yer verildiği belirlenmiştir. Aytan (2012: 131) çalışmasında, Türkçe $(6,7,8$.sınıflar) ders kitaplarındaki masal ve hikâyelerde sayg1, sabır ve vatanseverlik gibi karakter özellikleri tespit etmiştir.

\section{2. İkinci Alt Probleme İlişkin Sonuç ve Tartışma}

Araştırmanın ikinci alt problemi olan; "Sosyal Bilgiler dersi programına ait kazanımların karakter eğitimini gerçekleştirme düzeyi nedir?" sorusu doğrultusunda değerlendirme yapılmıştır.

Sosyal Bilgiler dersi (4-7. sınıflar) öğretim programı ortaokul düzeyinde incelendiğinde toplam 129 kazanımın 52'sinin (\%40) karakter eğitimi ile ilgili olduğu tespit edilmiştir. Balcı (2008) tarafından 6. sınıf seviyesinde gerçekleştirilen araştırmada değerler eğitimi programının öğrencilerin sosyal bilgiler dersi kapsamındaki değerleri edinmeleri noktasındaki etkisinin olumlu olduğu sonucu elde edilmiştir. Programda her ünitede karakter eğitimi ile ilgili en az bir kazanıma yer verildiği görülmektedir. Araştırma bulgularının tersine Ersoy ve Şahin (2012), 6. ve 7. sınıf sosyal bilgiler ders kitaplarını değerler eğitimi yaklaşımlarına uygunluğu açısından incelemiş ve bazı ünitelerde değerle ilgili hiç etkinlik bulunmazken, bazı ünitelerin tamamen değerlerle ilgili olduğunu tespit etmişlerdir. Ortaokul düzeyinde karakter eğitimi ile ilgili kazanımların sınıf seviyelerine dağılımına bakıldığında yaklaşık olarak eşit dağılım gerçekleştiği görülmektedir. Sosyal Bilgiler dersi ortaokul programında karakter eğitimi ile ilişkili kazanımlar ağırlıklı olarak vatandaşlık/vatanseverlik, sorumluluk ve adalet değerleri ile ilişkili olmakla beraber diğer kazanımlar ise hoşgörü, duyarlılık, dürüstlük, sayg1, öz-denetim/disiplin değerleri ile ilgilidir. 
Sosyal Bilgiler dersi ortaokul öğretim programında kazanımlarla ilişkili karakter özelliklerine bakıldığında; ortaokul düzeyinde vatandaşlık/vatanseverlik, sorumluluk, adalet, hoşgörü, duyarlılık, dürüstlük, saygı, öz-denetim/disiplin özelliklerine yer verilmiştir. Katılmış (2010) karakter eğitimi programının öğrencilerin barış değer düzeylerini yükseltmesinden dolayı Türk Milli Eğitim Sisteminin ve Sosyal Bilgiler dersinin barış, insan hakları ve demokrasi kapsamındaki amaçlarının da gerçekleştirilmesine hizmet ettiğini ifade etmiştir. Hoge (2002) Sosyal Bilgiler öğretmenlerinin öğrencileri dürüst vatandaşlar olarak yetiştirmek amacıyla derslerinde karakter eğitimi aktivitelerini kullanmaları gerektiğini belirtmiştir.

\section{3. Üçüncü Alt Probleme İlişkin Sonuç ve Tartışma}

Araştırmanın üçüncü alt problemi olan; "Fen Bilimleri dersi programlarına ait kazanımların karakter eğitimini gerçekleştirme düzeyi nedir?” sorusu doğrultusunda ilkokul ve ortaokul düzeyinde değerlendirme yapılmıştır.

Fen Bilimleri dersi öğretim programında karakter eğitimi ile ilgili kazanımlar değerlendirildiğinde ortaokul seviyesinde 252 kazanımın 37'sinin (\%15) karakter eğitimi ile ilişkili olduğu görülmektedir. Karakter eğitimi ile ilgili kazanımların duyarlılık, sorumluluk, cömertlik/yardımseverlik, vatandaşlık/vatanseverlik, merhamet/empati ve saygı (kendisine ve başkalarına) karakter değerleri ile ilgili olduğu belirlenmiştir. Fen Bilimleri dersi ortaokul öğretim programının karakter eğitimi ile ilişkisi sınıf düzeyleri bakımından incelendiğinde \%26 ile en yüksek oran yedinci sınıf düzeyinde ve ikinci olarak \%18 ile beşinci sınıf düzeyinde tespit edilmiştir Altıncı ve sekizinci sınıf programlarının her birinde ise karakter eğitimiyle ilişkili \%8 oranında kazanım bulunmaktadır. Genel olarak fen bilimleri dersi programında karakter eğitimi ile ilgili yeterli sayıda kazanıma yer verilmediği görülmektedir. Fen Bilimleri dersi içerik bakımından karakter eğitimini desteklemeye uygunken karakter eğitimi ile ilgili kazanım oranı düşüktür. Programda daha çok özel alan kazanımlarına yer verilmiştir. Tekbıyık ve Akdeniz (2017), Fen bilimleri eğitiminde özellikle sosyobilimsel konular ve sürdürülebilirlik gibi alanların, değerlerin entegrasyonu için firsat olarak görülebileceğini ifade etmiştir.

\section{Dördüncü Alt Probleme İlişkin Sonuç ve Tartışma}

Araştırmanın dördüncü alt problemi olan; Din Kültürü ve Ahlak Bilgisi dersi programına ait kazanımların karakter eğitimini gerçekleştirme düzeyi nedir?” sorusu doğrultusunda değerlendirme yapılmıştır. 
Din Kültürü ve Ahlak Bilgisi (4-8. sınıflar) öğretim programı değerlendirildiğinde toplam 232 kazanımın 101'inin (\%44) karakter eğitimi ile ilişkili olduğu görülmektedir.

Din Kültürü ve Ahlak Bilgisi dersi öğretim programı ortaokul düzeyinde incelendiğinde toplam kazanım sayısı 188, karakter eğitimi ile ilgili kazanım sayıs1 ise 74'dür (\%39). Sınıf düzeylerine göre değerlendirme yapıldığında beşinci sınıf düzeyinde 47 kazanımdan 20'sinin (\%43), altınc1 sınıf düzeyinde 47 kazanımdan 13'ünün (\%28), yedinci sınıf düzeyinde 50 kazanımdan 16'sının (\%32) ve sekizinci sınıf düzeyinde 44 kazanımdan 25 'inin (\%57) karakter eğitimi ile ilgili olduğu görülmektedir. Programda karakter eğitimi ile ilgili kazanımların vatandaşl1k/vatanseverlik, sevgi, saygı, merhamet/empati, hoşgörü, iyimserlik, yardımseverlik, sorumluluk, sabır, bütünlük/adalet, öz-denetim/disiplin ve duyarlılık özellikleri ile ilişkili olduğu tespit edilmiştir. Meydan (2012) Din Kültürü ve Ahlak Bilgisi öğretim programında bazı değerlerin kazanım ve konularla ilişkilendirildiğini ifade etmiştir.

\section{Beşinci Alt Probleme İlişkin Sonuç ve Tartışma}

Araştırmanın beşinci alt problemi olan; “Türkiye Cumhuriyeti İnkılap Tarihi ve Atatürkçülük dersi programlarına ait kazanımların karakter eğitimini gerçekleştirme düzeyi nedir?" sorusu doğrultusunda ortaokul düzeyinde değerlendirme yapılmıştır.

TC İnkılap Tarihi ve Atatürkçülük dersi öğretim programında 80 kazanım bü̈ lunduğu ve bu kazanımların 20'sinin (\%25) doğrudan karakter eğitimi ile ilişkili olduğu tespit edilmiştir. Karakter eğitimi ile ilgili bu kazanımların; vatanseverlik/vatandaşlık, sorumluluk, adalet, liderlik, iş birliği ve duyarlılık özellikleri ilgili olduğu belirlenmiştir. Ayrıca karakter eğitimi ile ilgili kazanımların ünitelere dağılımı incelendiğinde kazanımların eşit dağılmadığı, bazı ünitelerde hiç yer verilmediği görülmektedir.

\section{Altıncı Alt Probleme İlişkin Sonuç ve Tartışma}

Araştırmanın altıncı alt problemi olan; "Rehberlik ve Kariyer Planlama dersi programına ait kazanımların karakter eğitimini gerçekleştirme düzeyi nedir?” sorusu doğrultusunda değerlendirme yapılmıştır.

Rehberlik ve Kariyer Planlama dersine ait program incelendiğinde programda toplam 44 kazanımın yer aldığ 1 ve kazanımlardan 14'ünün (\%32) karakter 
eğitimiyle ilgili olduğu sonucu ortaya çıkmıştır. Programda yer alan karakter eğitimi ile ilgili kazanımlar, öz-denetim/disiplin, sayg1, sabır/ilgi, sorumluluk, vatandaşlık/vatanseverlik ve hoşgörü karakter değerlerine yöneliktir. Rehberlik ve Kariyer Planlama dersi, karakter eğitimini hem etkilemekte hem de bundan etkilenmekte olduğu için karakter eğitimiyle ilgili kazanımların yeterli olmadığ1 söylenebilir. Üstünyer (2009) yaptığı araştırma sonucunda eğitimcilerin Rehberlik derslerinin gerek program, gerekse uygulayıcılar açısından istenen katkıyı sağlamadığını vurguladıklarını ifade etmişstir.

\section{Yedinci Alt Probleme İlişkin Sonuç ve Tartışma}

Araştırmanın yedinci alt problemi olan; "Beden Eğitimi ve Spor dersi programına ait kazanımların karakter eğitimini gerçekleştirme düzeyi nedir?” sorusu doğrultusunda değerlendirme yapılmıştır.

Beden Eğitimi ve Spor dersi ortaokul programına ait kazanımlar değerlendirildiğinde programda 119 kazanıma yer verildiği ve bu kazanımların 40'ının (\%34) doğrudan karakter eğitimi ile ilgili olduğu tespit edilmiştir. Meydan (2012) programın amaçlarında ve kazanımlarında bu dersin gerçekleştirme imkânına sahip olduğu değerlere açık vurguların yapılmamış olmasını okulda çok boyutlu bir değerler eğitimi açısından eksiklik olarak değerlendirmiştir. Karakter eğitimi ile ilgili kazanımların ise; iş birliği, hoşgörü, sorumluluk, sayg1, duyarlıl1k, öz-denetim/disiplin, liderlik, vatandaşl1k/vatanseverlik, sportmenlik, yardımseverlik, bütünlük/adalet değerleri ile ilişkili olduğu tespit edilmiştir. Meydan'a (2012) göre öğrencinin okulda centilmenlik, özdenetim, yardımlaşma ve iş birliği gibi pek çok değeri yaşayarak öğrenmesine imkân verebilecek bir ders olması nedeniyle beden eğitimi dersleri ve sportif etkinlikler karakter eğitiminde özel bir öneme sahiptir.

Program sınıf düzeyleri açısından değerlendirildiğinde beşinci sınıf düzeyinde 30 kazanımın 9'unun, altıncı sınıf düzeyinde 30 kazanımın 10'unun, yedinci sınıf düzeyinde 31 kazanımın 12'sinin, sekizinci sınıf düzeyinde ise 28 kazan1mın 9'unun karakter eğitimi ile doğrudan ilişkili olduğu belirlenmiştir. Karakter eğitimi ile ilgili en çok kazanıma 7. sınıf düzeyinde yer verildiği görülmektedir. Programda karakter eğitimi ile ilgili kazanımlar incelendiğinde sınıf düzeyi arttıkça aynı kazanımlara genişletilerek yer verildiği görülmektedir. 


\section{Ortaokul Programlarının Tamamına İlişkin Sonuç ve Tartışma}

Bu başlık altında araştırma kapsamındaki ortaokul öğretim programlarının tamamına ait kazanımların karakter eğitimiyle ilişkisine yönelik değerlendirme yapılmıştır.

Programda ortaokul öğretim programlarına ait kazanımların \%19'u karakter eğitimi ile ilgilidir. Ortaokul programlarının tamamı değerlendirildiğinde Sosyal Bilgiler dersi öğretim programında karakter eğitimiyle ilgili kazanımların bu derse ait toplam kazanımlar içindeki oranının (\%40) en yüksek olduğu görülmektedir. Kazanımlar açısından en zengin ikinci ders Din Kültürü ve Ahlak Bilgisi (\%39) dersidir.

Beden Eğitimi ve Spor dersi ise karakter eğitimi ile ilgili kazanımları desteklemesi bakımından \%34 oran ile üçüncü sırada yer almaktadır. Bu dersleri sirayla Rehberlik ve Kariyer Planlama (\%32), İnkılap Tarihi ve Atatürkçülük (\%25) ve Fen Bilimleri (\%15) dersleri takip etmektedir. Tüm öğretim programları arasında kazanımların yüzdelik oran açısından en zayıf kaldığı derslerin başında Türkçe dersinin (\%3) geldiği görülmektedir. Türkçe dersinden sonra karakter eğitimini en az destekleyen ders Fen Bilimleri dersidir. Araştırmanın sonuçlarına paralel olarak Coşkun (2012) barış eğitimi ile ilgili yaptığı araştırmada Fen ve Teknoloji ve Türkçe derslerinin barış eğitimini desteklemede yetersiz kaldığını ifade etmiştir.

Ortaokul öğretim programlarındaki kazanımlar değerlendirildiğinde en çok dersle ilişkisi bulunması bakımından ilk sırada yer alan karakter değerinin, vatandaşlık/vatanseverlik değeri olduğu görülmektedir. Bu karakter değerinden sonra sayg1 (kendine, başkalarına ve mülkiyete), sorumluluk/güvenilirlik/hesap verebilirlik ve duyarlılık değerleri en çok dersle ilişkili karakter değerleridir. Aslan (2011), çalışmasında vatanseverlik, saygı ve sorumluluk/güvenilirlik değerlerinin öğretmen görüşlerine göre öğrencilere kazandırılması gereken karakter değerleri içerisinde en yüksek ortalamaya sahip değerler arasında olduğunu belirtmiştir. Ortaokul dersleriyle en az ilişkili karakter değerlerine bakıldığında alçakgönüllülük ve affetme değerlerinin herhangi bir dersin kazanımlarıyla ilişkisinin bulunmadığı belirlenmiştir. Bulach ve Butler (2002) yaptıkları araştırmada ortaokul düzeyinde karakter eğitimi açısından en büyük ihtiyacın sayg1, nezaket, affetme ve alçakgönüllülük olduğu sonucuna ulaşmışlardır. 


\section{Öneriler}

Bu bölümde araştırmada elde edilen sonuçlara yönelik önerilere yer verilmiştir.

1. Karakter eğitimi ile ilgili kazanımların yetersiz olduğu Türkçe ve Fen Bilimleri gibi dersler; kazanımlar açısından zenginleştirilebilir.

2. İncelenen ortaokul öğretim programlarının kazanımlarında yer almayan alçakgönüllülük ve affetme değerlerine uygun kazanımlar oluşturulabilir.

3. Sevgi, dürüstlük, iyimserlik, kibarlık/nezaket ve sportmenlik gibi karakter değerleri ile ilişkili kazanımların sayısı arttırılabilir

4. $\mathrm{Bu}$ araştırmada ortaokul derslerinden toplam 7 zorunlu dersin öğretim programı incelenmiştir. Seçmeli derslerle de benzer araştırmalar yapılabilir.

5. Öğretmenlerin karakter eğitimine yönelik görüşleri alınarak çalışma genişletilebilir.

\section{Kaynakça}

Almerico, G. M. (2014). "Building character through literacy with children's literature", Research in Higher Education Journal, 26(1).

Aytan, N. (2012). İlköğretim ikinci kademedeki Türkçe kitaplarındaki masal ve hikâyelerin karakter eğitimi açısından incelenmesi (Yüksek lisans tezi). Çanakkale Onsekiz Mart Üniversitesi Eğitim Bilimleri Enstitüsü, Çanakkale.

Aslan, M. (2011). İlköğretimde karakter eğitimi ve ögrrencilere kazandırılması gereken değerler (Yüksek lisans tezi). Eskişehir Osmangazi Üniversitesi Eğitim Bilimleri Enstitüsü, Eskişehir.

Bakioğlu, A. ve Sılay, N. (2014). Yüksekögrretim ve öğretmen yetiştirmede karakter eğitimi. Ankara: Nobel Yayınları.

Balc1, N. (2008). İlköğretim 6. sinlf Sosyal Bilgiler dersinde değerler eğitiminin etkililiği (Yüksek lisans tezi). Marmara Üniversitesi Eğitim Bilimleri Enstitüsü, İstanbul.

Bulach, C. R., \& Butler, J. D. (2002). The occurence of behaviors associated with sixteen character values, Journal of Humanistic Counseling, Education and Development, 41(2), 200-214.

Character Education Informational Handbook and Guide (2001). Department of Public instruction, public schools of North Carolina. Erişim adresi: http:// www.ncpublicschools.org/docs/charactereducation/handbook/content2.pdf_ 
Coşkun, Y. (2012). Illköğretim programlarında barış eğitimi ve barlş eğitimine ilişkin ögretmen görüşleri. Gaziosmanpaşa Üniversitesi Eğitim Bilimleri Enstitüsü, Tokat.

Ekşi, H. ve Katılmış, A. (2015). Karakter eğitimi el kitabı. İstanbul: Nobel Yayınları.

Ersoy, F., ve Şahin, T. (2012). Sosyal bilgiler ders kitaplarının değerler eğitimi yaklaşımları açısından incelenmesi, Kuram ve Uygulamada Eğitim Bilimleri Dergisi, 12(2), 1535-1558.

Hoge, J. (2002). Character education, citizenship education, and the social studies. The Social Studies, 93(3), 103-108.

Katılmış, A. (2010). Sosyal Bilgiler derslerindeki bazı değerlerin kazandırılmasına yönelik bir karakter eğitimi programının geliştirilmesi (Doktora tezi). Marmara Üniversitesi Eğitim Bilimleri Enstitüsü, İstanbul.

Meydan, H. (2012). İlköğretim okullarında değerler ve karakter eğitimi (Doktora tezi). Sakarya Üniversitesi Sosyal Bilimler Enstitüsü, Sakarya.

Tekbıyık, A., ve Akdeniz, A. R. (2017). Fen bilimleri eğitimine değerler eğitiminin entegrasyonu üzerine bir değerlendirme. Pegem Attf İndeksi, 129-138.

Üstünyer, F. (2009). Karakter eğitimi ile ilgili eğitimcilerin görüssleri üzerine nitel bir araştırma (Yüksek lisans tezi). Yeditepe Üniversitesi Sosyal Bilimler Enstitüsü, İstanbul.

Yalız, D. (2011). Beden Eğitimi dersi kapsamındaki fiziksel etkinlik oyunlarının ilköğretim öğrencilerinin karakter gelişimleri üzerindeki etkisi (Doktora tezi). Anadolu Üniversitesi Sağlık Bilimleri Enstitüsü, Eskişehir. 


\section{Character Education Analysis of Secondary School Curriculum Attainments}

Özlem GÖKÇE TEKIN, Corresponding Author, Phd Student. İnönü University.Institute of Education Sciences.

E-mail: ogokcetekin@gmail.com

ORCID: ORCID: 0000-0002-4436-3060

Gülay BEDIR, Assoc. Prof.

Kahramanmaraş Sütçü İmam University, Faculty of Education,

E-mail: gulaybedir@hotmail.com

ORCID: 0000-0003-3488-6340

\section{Introduction}

In recent years, incidents such as violence, terrorism and fraud that are disturbing the social order have been increasing both in our country and abroad. The occurrence of these events is deeply rooted in the character traits of people. Thus, it is inevitable that individuals with negative characteristics will harm society as well as themselves. The character is defined according to the Turkish Language Association in the most general way as the unique structure of an individual, the basic feature that differentiate him/her from others and the superior, main characteristic and self-structure that determine the behavior patterns of the individual.

Character education, aims to raise individuals who have an understanding of moral values and can choose the right one, by enhancing the skills and ability of the student to decide how to behave appropriately in various social settings (Almerico, 2014). The school environment is very important for character de- 
velopment. When adolescence coincides with secondary school age and is considered as a continuation of childhood, it can be said that secondary school has a great importance in character education (Yalız, 2011). This study is an important study in terms of examining to what extent the attainments in secondary education curriculum are related to character education. Bearing in mind that Turkey is rather limited in this area, this study is expected to contribute to this field of research.

\section{Purpose}

The purpose of this study is to determine to what extent the attainments of some courses in secondary school programs support the character education. For this purpose, answers to the questions about how much of the attainments of the following courses are related to character education were sought.

1. Turkish

2. Social Studies

3. Science

4. Religious Culture and Ethics

5. T. C. Revolution History and Kemalism

6. Guidance and Career Planning

7. Physical Education and Sports

\section{Methodology}

The universe of the research has been formed with the curriculum of all the courses of secondary schools. The sample of the research has been formed with compulsory courses at secondary level in 2015-2016 academic year.

Descriptive research model was used in this study. In the process of obtaining the data, the secondary education programs accepted by the Board of Education and Discipline (BoED) were reached and the attainments in these programs were grouped according to the classes and grade levels.

Documentation Technique was used for the examination of the related programs. The attainments in specified courses are discussed in terms of content and scope of character education as a whole. 19 character values were determined for the analysis of the curriculum. 16 of these are the basic character values determined by Bulach and Butler (2002). These are; respect for self, others and property, humility, self-control/discipline, honesty, responsibility/depend- 
ability /accountability, perseverance/diligence, cooperation, integrity/fairness, compassion/empathy, forgiveness, patriotism/citizenship, kindness, tolerance/ diversity, courtesy/politeness, generosity/charity and sportsmanship. At the end of the literature review, character values of Bulach and Butler (2002) values such as love, sensitivity and leadership were added to the character values .

\section{Findings}

There are a total of 496 attainments in the Turkish language secondary school program and only $17(3 \%)$ of these attainments are related to character education. It is determined that there are 262 attainments at the fifth grade level in the program and $13(5 \%)$ of these are related to character education. There are 234 attainments in grades 6,7 and 8 , and only $4(2 \%)$ of these are related to character education. At the 6 th, 7 th and 8 th grade levels, the attainments are not given on the basis of separate classes and the attainments are gathered under the titles of learning areas. Attainments in the fifth grade program relate to the values of character of respect, self-control/discipline, cooperation and citizenship/ patriotism and sensitivity. In grades 6,7 and 8 , it is associated with the values of respect, courtesy/politeness and perseverance.

In the Social Studies curriculum, there are 129 attainments at secondary level and $52(40 \%)$ of these attainments are related to character education. It is seen that each unit has at least one attainment related to character education. When the distribution of the attainments related to character education according to the class levels is examined, it is seen that there is approximately equal distribution. It is determined that the attainments are mainly related to the character values of citizenship/patriotism, responsibility and fairness. Other attainments in character education relate to tolerance, sensitivity, honesty, respect, self-control/discipline.

When the attainments in Science course of secondary school program are examined, it is found that there are 44 attainments at the fifth grade level, 52 attainments at the sixth grade level, 78 attainments at the seventh grade level and 78 attainments at the eighth grade level. There are 252 attainments in the secondary school curriculum. 37 of the current attainments (about 15\%), are related to character education. Of the 37 attainments with character education, 16 belong to the seventh grade and 11 to the fifth grade. In the sixth and eighth grades, there are 5 attainments related to character education. It has been found that the attainments in character education are concentrated on sensitivity, re- 
sponsibility, generosity/charity, compassion/empathy, citizenship/patriotism and respect for self and others.

There is a total of 188 attainments in the Middle School Religious Culture and Ethics Program. 74 (39\%) of these are directly related to character education. It is seen that 20 of 47 attainments (43\%) in fifth grade level, 13 of 47 attainments $(28 \%)$ in sixth grade level, 16 of 50 attainments (32\%) in seventh grade level and 25 of 44 attainments (57\%) in eighth grade level are related to character education. Regarding this program, it is found that values related to the attainments are citizenship/patriotism, love, respect, compassion/empathy, tolerance, kindness, charity, responsibility, perseverance, integrity/fairness, self-control/ discipline and sensitivity.

It has been determined that there are 80 attainments in the Atatürk's Principles and History of Turkish. Twenty (25\%) of the current attainments are directly related to character education. When the attainments directly related to character education in the program are examined, it is found that the attainments related to character value are patriotism/citizenship, responsibility, fairness, leadership, cooperation, and sensitivity.

When the attainments in the Guidance and Career Planning curriculum are examined, it is seen that there are a total of 44 attainments, of which 14 (32\%) are related to character education. Character values related to the attainments are as follows; self-control/discipline, respect, perseverance/diligence, responsibility, citizenship/patriotism and tolerance.

It has been determined that 119 attainments are included in the secondary school Physical Education and Sports curriculum and 40 of these attainments (34\%) are directly related to character education. 9 of 30 attainments at fifth grade level, 10 of 30 at sixth grade level, 12 of 31 at seventh grade level and 9 of 28 at eighth grade level are directly related to character education. Thus, it is seen that the most attainments related to character education is given in seventh grade level ( $f=12$ ). Attainments related to character education in these curriculum are; cooperation, tolerance, responsibility, respect, sensitivity, self-control/ discipline, leadership, citizenship/patriotism, sportsmanship, charity and integrity/fairness. 


\section{Conclusions and Recommendations}

According to the results of the analysis of the related program, $19 \%$ of the attainments of secondary school curriculum are related to character education. Character education in secondary level is supported almost all of the courses. The most supportive course is Social Studies. This course is followed by Religious Culture and Ethics and Physical Education and Sports courses. Furthermore, it is found that lessons that considered insufficient in terms of the attainments related to character education are Turkish and Science.

When the attainments in secondary school curricula are evaluated, it is seen that the character value which comes first for its refrence in the course is the value of citizenship/patriotism. After this character value, respect (self, others and property), responsibility/dependability/accountability and sensitivity values are the most related character values. Least associated with secondary school courses are found to be values of humility and forgiveness that do not have any relation with the attainments of any course

According to the survey, firstly it may be recommended that secondary school education programs can be enriched and expanded in accordance with the content and context of character education. It is seen that Turkish and Science courses are insufficient in terms of the attainments related to character education. In this context, especially these courses can be enriched in terms of attainments associated with character education. And the small number of attainments associated with character values such as love, honesty, optimism, kindness / courtesy and sportsmanship may be increased. 